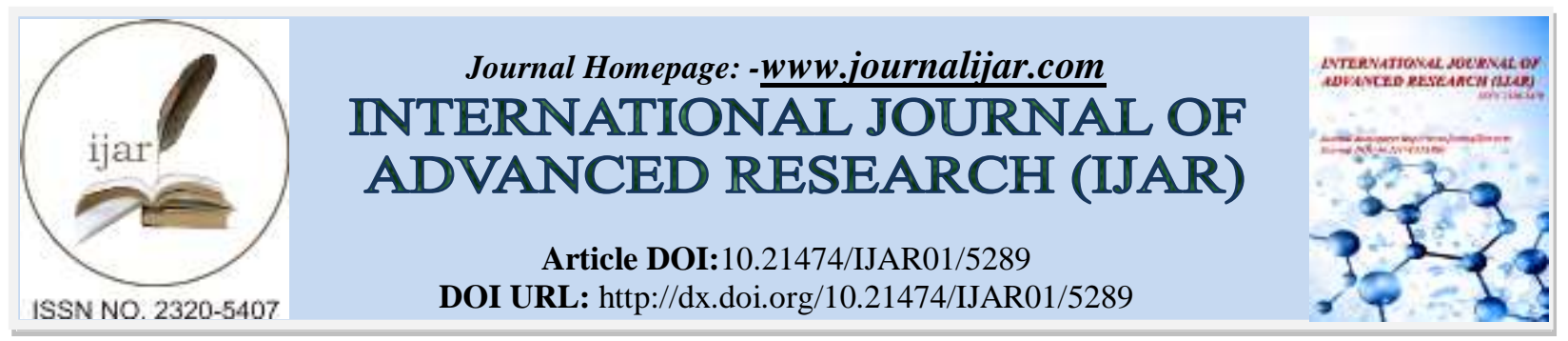

RESEARCH ARTICLE

\title{
IMPACT OF IMPLEMENTATION OF GREEN SUPPLY CHAIN MANAGEMENT PRACTICE IN PRODUCTION INDUSTRY: A REVIEW.
}

\author{
Dr. Santanu Kumar Ghosh. \\ Department of Mathematics, Kazi NazrulUniversity, Asansol, West Bengal, Pin-703340.
}

\section{Manuscript Info}

Manuscript History

Received: 26 June 2017

Final Accepted: 28 July 2017

Published: August 2017

Key words:-

Green supply chain management, Asian Industries, Manufacturing sectors, Corporate \& Social Responsibility.

\begin{abstract}
Green Supply Chain management means environment friendly supply chain management in industries. There are different motivators for companies to switch to 'green' in their supply chain. Ordinary supply chain management involves several extraction and exploitation of the natural resources. But now a day, the environmental sustainability has been an important issue to business practice. Since the early 1990's, manufacturers have been faced with pressure to address Environmental Management (EM) in their supply chains. Adding the 'green' concept to the 'supply chain' concept adds a new paradigm where the supply chain will have a direct relation to the environment. The green supply chain also includes reduction of usage of raw materials, recycling, reuse and the substitution of materials etc. The practice of monitoring of environment friendly purchasing, manufacturing, supplying, marketing, delivering of the final product to the consumer are also parts of green supply chain management.
\end{abstract}

Copy Right, IJAR, 2017,. All rights reserved.

\section{Introduction:-}

In the last two decades, the rapid industrial modernizations and globalizations have expanded various industries drastically. This change has created numerous opportunities for economic growth and employment as well as challenges related to availability of resources and environment management. These industrial modernizations also lead to negative environmental impacts including greenhouse gas emissions etc. Therefore, many researchers have devoted their attention towards the sustainability of environment. Green supply management can also be represented by the following.

$\mathrm{GSCM}=$ Green purchasing + Green manufacturing/materials management + Green Distribution / marketing + Reverse logistics+ Waste Management.

The concept of use of green supply chain management in industry is new. Although numerous models of production-inventory models have been developed theoretically but the implementation of green or environmentfriendly supply chain management in the industries of the Asian county is still limited.

In response to the growing global environmental awareness, green supply chain management (GSCM) has emerged as a concept that considers sustainability elements and a combination of environmental thinking along the intra- and inter-firm management of the upstream and downstream supply chain (Walker and Jones (2012), Zhu et al.(2007a,b, 2008a,b, 2012)). Moreover, manufacturers of the majority of products that are consumed in the developed countries relocated their manufacturing bases and production facilities in Asian 
Emerging Economies (AEE) (Lai and Wong (2012), Tang and Zhou (2012)). This relocation to Asia was primarily rationalized by cheap labor and low material costs as discussed by Lai et al. (2013). Meanwhile, the increasing global awareness around environmental impact of production processes is placing an escalating pressure on manufacturers not only in the developed world but also in emerging economies in Asia.

\section{Literature Review:-}

The concept of the term 'supply chain' was first introduced by Banbury (1975). According to him, 'supply chain' is passing on electricity towards the ultimate consumer. However, that the term 'supply chain management' first came into the context after 1980. Oliver and Webber (1982) discussed the potential benefits of integrating internal business functions of purchasing, manufacturing, sales and distribution into one cohesive framework. Stevens (1989) has defined supply chain management as the integration of business functions involving the flow of materials and information from inbound to outbound ends of the business. Relationships, chains and networks in supply chain was discussed by Harland (1996). The state-of-the-art in integrating supply chain management (SCM) was examined by Stevens (1989).

Closer and long-term relationships with suppliers in several industries was discussed by Hakansson (1987), Lorenzoni and Ornati (1988), Womack et al. (1991), Lamming (1993), Nishiguchi (1994). The increasing dependence on suppliers was discussed by Slack (1991) and Christopher (1992). The terms 'partnership' and 'partnership sourcing' have been used to refer to these closer, longer relationships with suppliers. These long-term orientations support most recent findings, which discover that once transactors have made the up-front investment to develop self-enforcing safeguards such as relational trust, the transaction costs decline in the long term because selfenforcing safeguards can control opportunism over an indefinite time horizon (Dyer 1997). Specifically, the transaction costs and inventory holding costs associated with arm's-length bidding practices, characterized by shortterm relationships with a large number of short-term suppliers, can actually outweigh the costs of the parts themselves (Dyer 2000). Wood (1997) argues that firms need to become more integrative amongst other firms to reduce the vulnerability of the supply chain. There are various case studies where firms were becoming more integrative to their supply chain partners. Lamming (1993) and Womack, Jones and Roos (1990) mentioned the Japanese automotive industry and the Italian craft-based industry as basic examples.

Green supply chain management (GSCM) is an emerging field that strands out of the traditional supply chain perspective. GSCM has gained popularity with both academics and practitioners to aim in reducing waste and preserving the quality of product-life and the natural resources. As per Ashley (1993) and Srivastava (2007), ecoefficiency and remanufacturing processes are important assets to achieve best practice Global market demands and governmental pressures are pushing businesses to become more sustainable (Guide \& Srivastava, (1998), Gungor \& Gupta (1999)). Walton, Handfield and Melynyk (1998, p. 2) even claimed that "increasing government regulation and stronger public mandates for environmental accountability have brought these issues into the executive suites, and onto strategic planning agendas." The key themes that came out in the literature over the last twenty years are the concepts of: green design, green operations, reverse logistics, waste management and green manufacturing (Guide \& Srivastava, (1998), Srivastava (2007)). The very first green supply chain came into context in 1989. Kelle and Silver (1989) were the first of this literature that developed an optimal forecasting system for organizations to use to forecast products that can be potentially be reused. This forecasting system, however, was highly contentious because returning individual containers is not usually known with certainty, so therefore, their findings may somewhat be incoherent.

There are large amounts of literatures that surround GSCM, especially from 1989 to the present. But the key themes that came out of the GSCM literature over the last twenty years are the concepts of green design, green operations, reverse logistics, waste management and green manufacturing (Guide \& Srivastava, 1998; Srivastava, 2007).

\section{Green Design:-}

Green design is a vital area in Green supply chain management. The first green design literature came into context in 1991. Navin Chandra (1991) was the first of the literature to consider the need for a green design to reduce the impact of product waste. Works of Ashley (1993), Allenby and Richards (1994) and Zhang, Kuo, Lu and Huang (1997) came into context and expanded the framework of green design. Life-cycle analysis was an example of a framework that came out of green design. Works of Arena, Mastellone and Perugini (2003), Beamon (1999) and De Ron Penev (1995) all discussed life-cycle analysis as a framework. It is about planning an item or an administration that supports natural mindfulness. Fiksel (1996) suggested that associations can possibly get to be eco- 
accommodating towards item re-producing. Substantial enterprises that have complex supply chains ought to think about the advantages of reverse logistics (RL). Beamon (1999) recognized the improvement of ISO14000. This was presented as an aftereffect of the Rio Summit on the Environment in 1992. There are developing weight gathers that calls for firms to empower "greening" in the supply chain. There are numerous literary works that identify with Green Design. Barros et al. (1998) proposed a two-level model on product recuperation with the support of the Dutch government. Johnson (1998) analyzed the part of acquiring reverse logistics framework and plan. In this review, twelve American manufacturing plants took part and it gives the idea that every one of them were supportive of reverse logistics without government enactment having been forced. Taleb and Gupta (1997) made connected calculations to outline an item recuperation framework. This review demonstrates that 'center calculations' and 'assignment calculations' are the planning frameworks that would diminish squander.

\section{Green Operation:-}

Green Operations in terms of reverse logistics was an important concept that came out of the GSCM literature. Apart from Kelle and Silver's(1989) article, works of Pohlen and Farris (1992), Stock (1998) and Tibben and Limbke (2002) all provided case studies on reverse logistics. The use of plastics and bottle recycling are mentioned in some of these articles. Carter and Ellram, (1998), Srivastava and Srivastava, (2006), Shih (2001), Nagorney and Toyasaki (2005) and Min, Ko and Ko, (2006) are all academic perspectives of reverse logistics. Waste management is another topic that came out of the GSCM literature. This came into prominence with the work of Roy and Whelan (1992). This article created a standardized model for reducing electronic waste without harming the environment. After this article, different waste management issues came into context particularly around recycling. Works like Hanna and Newman (1995), Sarkis and Cordeiro (2001) and Nagorney and Toyasaki (2005) are all examples of trends of waste management becoming an issue. Green Manufacturing, on the other hand, was not conceptualized until 1993 in the work of Crainic, Gendreau and Dejax (1993). This article established a comprehensive green supply chain model in terms of transporting containers from land to sea and vice-versa. Ideas of green manufacturing were then developed further by Van Der Laan \& Salomon (1997), Guide and Srivastava (1998) and White, Masanet, Rosen and Beckman (2003). There are other comprehensive reviews around GSCM, particularly in the late 1990's where issues such as green production and planning and manufacturing (Bras \& McIntosh(1999), Sarkis \& Cordeiro (2001), Van der Laan, Salomon \& Dekker (1996)) and product recovery (Gungor \& Gupta, (1999), Van Der Laan et al. (1996)) are discussed. Barros, Dekker, and Scholten (1998) discuss recycling in the supply chain and Darnall, Jolley, Jason and Harnfield (2008) critique GSCM by saying that Environmental Management Systems (EMS) are making less progress in reducing environmental harms. Some studies, however, are of limited focus. Van Der Laan et al. (1996) only discussed product remanufacturing and disposal, and Zhang et al. (1997) only discussed environmental technologies and design. Journals that are useful to GSCM are Organisations and the Natural Environment, Business Strategy and Environment and Journal of Operations Management. According to Beamon (1999), Supply Chain Management is a process wherein raw materials are converted into final products and then they are delivered to the end-consumer.

\section{Green Manufacturing \& Remanufacturing:-}

This stage involves the manufacturing of products in a way that reduces the total requirement of resources including material and energy. This helps reduce pollution and waste and contributes toward the overall goal of meeting the requirements of GSCM. This might include reengineering, retooling and other similar techniques to make systems leaner and hence green. Some popular techniques used nowadays include Six Sigma manufacturing, lean manufacturing, just in time inventory (JIT) and the incorporation of Total Quality Management (TQM) in the production processes. Six Sigma was developed by M/s Motorola. This concept involves removal of defects/ errors across the production chain. This helps remove uncertainty in decision making. Specialists are trained for this purpose and are identified through the nomenclature of different belts that identify their level of expertise. Lean manufacturing aims to remove waste across the production process by identifying and targeting resources that do not add any value to the product. JIT was devised by the people at M/s Toyota, Japan. Instead of having a safety stock the materials are requisitioned right at the moment they are needed. Issues such as supplier delays, poor forecasts or quality issues are faced head on. Moreover instead of pushing everything through the chain, a pull is followed across the workstations towards the completion of the job. Eventually, this reduces the inventory carrying cost but it also increases potential risk. One of the ways to achieve JIT is through Vendor Managed Inventory (VMI). This includes buyer supplied information that helps vendor make informed decisions regarding inventory management. TQM involves being proactive in performing the right activity, the right way, the first time and continuing to perform it to the required level. The focus is towards moving from q (quality assurance) to $\mathrm{Q}$ (total quality). Other techniques 
used in green manufacturing include the employment of Quality Function Deployment (QFD), Taguchi matrices, Enterprise Feedback Management (EFM) systems, etc.

Remanufacturing involves the disassembly and recovery of obsolete components. These components can then be reused in assembly or sub assemblies across primary and/or secondary markets. The particular remanufacturing process will involve the condition of the product received after disposal. This can involve resale of the product in second-hand markets; repair of the components to restore functionality; recycling to make the product or some of its components reusable. The most obvious objective of remanufacturing is cost reduction. Hence remanufacturing should always be preceded by a cost-benefit analysis. Other potential benefits include reduction of the carbon footprint, certifications, green branding, aid in CSR reports, etc. Currently the size of the market in remanufacturing includes 5 billion pounds/year in the UK (Gray, 2007) and \$ 40.5 billion in the USA (Remanufacturing Institute, 2003).

Lean and Just-In-Time (JIT) Management have added factors that helped enhanced the operational processes of the supply chain (Wood (1997), Power (2005)). The requirement for organisations to become actively responsive to the needs of customers has increasingly been important (Christopher, (2000)). Power (2005) observes that speed (delivering customer demand quickly), agility (responsiveness to customer demand) and leanness (doing more with less) are the contributing factors that would make firms more competitive.

\section{Reverse Logistics \& Network Design:-}

Reverse logistics differs from forward logistics due to its design and scope. Its design includes the provision of transportation, inventory and other facilities for the product returning from the market. The return can take the form of a product, collected, after the completion of its useful life or a product returned by the customer due to functional reasons. The later type includes examples such as manufacture recall programs, Return to Origin (RTO) resulting from customer refusal to receive the product, installation or usage problem, warranty claim, faulty order processing, retail overstock, etc. Reverse logistics is meant to facilitate the extraction of remaining usability in the product in the reverse side of the green supply chain. The main players in the returns process include companies that take on producer's responsibility towards the disposal of the product after obsolescence, specialized 3PL companies and government bodies. Vendors, developers and consultants of technology, infrastructure and software for managing reverse flows are also interested in the growing area of RL practices. The product recovery process takes place in the shape of resale, repair, reuse, remanufacture/refurbish, recycle and/ or scrap. This industry is growing and resulting in the need for specialized services and technology. The advantage of keeping RL in-house is to protect IP rights. On the other hand, 3PL acts as a specialized option which is used by a company to concentrate on its core competencies. Independent operators are usually junk dealers. The main issues in the returns process include uncertainty and low margins. However such problems can be mitigated by improving product life cycle, designing a product for reassembly (e.g. automotive industry) and recycling. Again, it is still a growing field and a subject of ongoing research. According to Scott et al (2011), three golden rules must be followed in returns management. First, returns must be treated as perishables: Every delay in transporting, sorting, processing and repacking of returned printers, for example, reduces the value remaining in the product. Second, value chain partnerships in reverse logistics are crucial. Specialized 3PL providers can often handle tasks such as credit issuance and product disposition much more efficiently than manufacturers. Thirdly, returns can provide valuable customer feedback. A well-managed reverse supply chain allows the manufacturer to retain contact with the customer and gather valuable feedback from them. This customer feedback can be used to adapt the product mix and to correct any failings in product design and distribution infrastructure. An important issue to counter at this stage includes the specialized network design for reverse logistics. This is difficult because of the inherent uncertainty about the returns. It is difficult to forecast the return accurately. The network designed for RL should be flexible enough to meet fluctuations yet it should also be stable in terms of rules and policies.

\section{Waste Management:-}

This stage involves all the efforts geared towards productive management of waste. This also includes the design and location of the relevant waste management sites and procedures. The procedures might vary from landfill and incineration to recycling. The sites might be selected based on cost and logistics strategy of the firm. One of the metrics of waste management in GSCM is the impact of the policy on the environment. To this end different methodologies have been adopted to measure the impact of such strategies and design better ones. For instance according to (Srivastava, 2007) by implementing 'green' design into GSCM, the produced products will be environmentally friendly and their components will be fully recycled. This would make waste management a much 
easier and more successful process. However, if companies are not able to create recyclable goods and, thus, reduce waste production, then the whole product life cycle will fail to be 'green', regardless of how efficient their logistics processes are.

The recent contributions in this research field came from the researchers Kumar, S., Luthra, S. \& Haleem, A. (2013, 2014), Kaushik, A., Kumar, S., Luthra, S., \& Haleem, A. (2014) etc. Issues in environmentally conscious manufacturing and product recovery was discussed by Gungor, A., \& Gupta, S. M. (1999). Strategic intent in Supply Chain Management was discussed by Hamel, G. \& Prahalad, C.K. (1989). Sustainable supply chain management in British Aerospace (BAe) Systems was studied by Gopalakrishnan, K., Yusuf, Y. Y., Musa, A., Abubakar, T., \& Ambursa, H. M. (2012). The difficulties in implementing sustainable supply chain management in Indian automobile sector was discussed by Luthra, S., Kumar, V., Kumar, S., \& Haleem, A. (2011) \& Luthra, S., \& Haleem, A. (2015).

The difficulties in implementing sustainable supply chain management in Indian automobile sector was discussed by Luthra, S., Kumar, V., Kumar, S., \& Haleem, A. (2011),. The critical success factors to implement green supply chain management sustainability in Indian perspective was discussed by Luthra, S., Kumar, S. ,Garg, D., \& Haleem, A. (2015). The adoption of green supply chain management practice \& its impact was discussed by Mitra, S. Dutta, P.P. (2014). The key enablers to implement sustainable supply chain management practice in India was discussed by Kausar, K., Garg, D. and Luthra, S.(2017). The building theory of GSCM using total interpretive structural modeling was dis cussed by Dubey, R., Gunasekaran, A., Wamba, S.F. and Bag, S. (2015). Evolutionary green approach for the analysis of green supply chain management was studied by Barari, S., Aggarwal, G., Zhang, W.C., Mohanti, B. and Tiwari, M.K.(2012).

\section{Environmental impact :-}

Although, to keep industry eco-friendly and maintaining corporate \& social responsibilities, a portion of the investment is made, a reasonable profit of the company may be increased. This may lead to good reputation of the company. Consequently, a considerable increase of selling is expected. The exemption of tax from the government may be imposed for producing environment friendly products. The reduction of transport and hence transportation cost may lead to gain of more revenue of the company. The practice of corporate \& social responsibilities of the company may attract quality employees which may turn increase of more profits. Correct recycling techniques and ways to maintain paperless environment may lead to greater profit. Also reuse of items in the production process have dual benefits. One is to reduce non-biodegradable products in the environment and the second is to reduce to production cost of the product. The expected outcome of the project is to make a eco-friendly, eco-environment production process where the eco-friendly produced goods are to be distributed among the retailer. It is expected that the usage of such eco-friendly production process ultimately increases to make more profit.

\section{Green Supply Chain Management Research Methodology:-}

Dowlatshahi (2000) suggested that the Reverse Logistics (RL) is mainly a practitioner based view. But there are several comprehensive academic journals, particularly quantitative studies, which show and support reverse logistics. A mathematical reverse logistic model in electrical appliances in Japan was established by Umeda, Y., Tsukaguchi, H., \& Li, Y. (2003). They were motivated to develop this model due to the implementation of new governmental regulations. Ravi, Ravi and Tiwari (2005) established an Analytical Network Process (ANP) based decision model to enhance reverse logistics for EOL Computers. This study used a balance scorecard approach that has four different dimensions (customer, internal business, innovation and learning and finance) to enhance the validity of the model. An integrated framework to reduce electronic waste was developed by Nagorney and Toyasaki (2005). In their study, multi-tiered e-cycling network equilibrium model was used to enhance the reverse supply chain. This model can be applied to a variety of recycling issues and policies in Japan and the European

Union. There are also qualitative studies done on Reverse Logistics, mainly in the forms of surveys and semistructured interviews. Guide and Srivastava (1998) have based their methodology on using semi-structured interviews and surveys to managers in remanufacturing facilities. In this study, managers used inventory buffers (delay buffers) to aid coordination and control in the flow parts of remanufacturing and reassembly stages of the chain. Rao and Holt (2005) used questionnaires to ISO14001 certified companies in South East Asia. Zhu and Sarkis (2004) made a survey to 186 manufacturing enterprises in China in remanufacturing. Cairncross (1992), Kopicki, Legg, Berg, Dasappa and Maggioni (1993) and Gatenby and Foo (1990) are studies that are more theoretical in regards to environmental consciousness of the supply chain. 


\section{Contemporary Practices in Green Supply Chain Management:-}

When the world is approaching towards the globalization, it can be reasonably presumed that there will be a universal standardization of best practices in the realm of supply chain management. To reduce global warming and environmental pollution, the necessity of implementation of GSCM has been accepted by many countries. . A study on Fortune 500 Global list of companies shows that "over two-thirds of the firms are producing some type of sustainability report. This is an indication of the level of importance and commitment from large companies..... It appears that companies are slowly and gradually turning their attention to potential environmental benefits in the global supply chain." (Wu et al, 2012). The current focus seems to be on achieving ISO 14000 certifications, emission reductions, reducing energy consumption, green logistics, green packaging, etc.

\section{China:-}

The circular economy (C.E.) is used by the Government of China. Circular Economies are based off the 3R principle, being reduce, re-use, recycle. Reduce refers to a method of improving efficiency, where the input of resources are reduced and output levels are increased. Re-use is the implementation of integrated systems that uses recycled material in the input stage of the manufacturing process, where there is a less reliance on raw materials. The recycling principle revolves around implementing strategies that transform collected waste and normal output into a resource that can be used.

\section{Netherlands:-}

Netherlands has an industrial park working on the principles of industrial symbiosis. All of the resources are exchanged in a closed cycle. The residual waste of one unit becomes the input of another.

\section{Japan :-}

Japan has a law that aims at creating provisions for a society in which virgin material inputs are minimized. This is aimed at reduction in pollution. This initiative was also adopted by G8 in the form of Kobe-3R plan in 2004.

\section{Germany:-}

A circular economy (C.E.) law was implemented by the government in 1996. This law makes the producers responsible for the product throughout its life cycle.

\section{Denmark:-}

Denmark has adopted Extended Producer Regime (EPR) whereby the environmental costs of the product are incorporated into its final market price. In this way the producer becomes responsible for the final disposal of the product.

USA :-

USA adopted Resource Recovery Act, 1976 (RCRA) which deals with the disposal of solid and hazardous waste. It also envisions industrial ecology to be en vogue across the USA by 2020.

\section{Conclusion:-}

The purpose of this paper is to briefly provide an overview of the Green supply chain literature and also to examine whether GSCM practice adopted by different production industries actually helped to reduce the ecological impacts of industrial activity. Different researchers viewed GSCM in different dimensions and some of them described reverse logistics whereas some others have described as life-cycle analysis. The paper discussed briefly the concept of green design, green operations, reverse logistics, waste management and green manufacturing in GSCM in last twenty five years.

Although the paper reviewed GSCM comprehensively, there are areas around Green supply chain that still require further study. The stakeholder's view towards the implementation of supply chain may be focused in the future studies of Green supply chain management.

\section{Bibliography:-}

1. Allenby, S., Richards, D. (1994). The greening of industrial eco-systems. Washington: National Academic Press.

2. Arena, U., Mastellone, M. L., \& Perugini, F. (2003). The environmental performance of alternative solid waste management options: A life-cycle assessment study. Chemical Engineering Journal, 96, 207-222. 
3. Ageron, B., Gunasekaran, A., \& Spalanzani, A. (2012). Sustainable supply management: An empirical study. International Journal of Production Economics, 140(1), 168-182.

4. Ashley, S. (1993). Designing for the environment. Mechanical Engineering, 115(3).

5. Beamon, B. (1999). Designing the green supply chain. Logistics InformationManagement, 12(4), 332-342.

6. Balasubramanian, S. (2012). A hierarchical framework of barriers to green supply chain management in the construction sector. Journal of Sustainable Development, 5(10), 15-27.

7. Banbury, J. G. (1975). Distribution - the final link in the electricity-supply chain. Electrics and Power Journal of the Institution of Electrical Engineers, 21(13), 773-775.

8. Brass, B., \& McIntosh, M. W. (1999). Product, process, and organizational design for remanufacture - an overview of research. Robotics and Computer-Integrated Manufacturing, 15, 167-178.

9. Barari, S., Agarwal, G., Zhang, W. C., Mahanty, B., \& Tiwari, M. K. (2012). A decision framework for the analysis of green supply chain contracts: An evolutionary game approach. Expert Systems with Applications, 39(3), 29652976.

10. Barros, A. I., Dekker, R., \& Scholten, V. (1998). A two-level network for recycling sand: A case study. European Journal of Operational Research, 110, 199-214.

11. Cairncross, F. (1992). Costing the earth. Boston: Harvard Business School Press

12. Carter, C. R., \& Ellram, L. M. (1998). Reverse logistics: A review of the literature and framework for future investigation. Journal of Business Logistics, 19, 85-102.

13. Christopher, M. G. (1992). Logistics and supply chain management. London: Pitman Publishing.

14. Christopher, M. (2000). The agile supply chain - competing in volatile markets. Industrial Marketing Management, 29(1), 37-44.

15. Crainic, T. G., Gendreau, M., \& Dejax, P. (1993). Dynamic and stochastic models for the allocation of empty containers. Operations Research, 41, 102-126.

16. Darnall, N., Jolley, G. J., \& Handfield, R. (2008). Environmental management systems \& green supply chain management: Complements for sustainability? Business Strategy \& Environment, 17(1), 30-45.

17. De Ron, A., \& Penev, K. (1995). Disassembly and recycling of electronic consumer products: An overview. Technovation, 15, 407-421.

18. Dowlatshahi, S., 2000, Designer-buyer-supplier interface: theory versus practice. International Journal of Production Economics, 63, 111-130

19. Dyer, J. H., 1997, Effective interfirm collaboration: how firms minimize transaction costs and maximize transaction value. Strategic Management Journal, 18, 535-556.

20. Dyer, J. H., 2000, Collaborative Advantage: Winning through Extended Enterprise Supplier Networks (New York: Oxford University Press).

21. Dubey R., Gunasekaran A., Wamba S.F., \& Bag S. (2015a). Building theory of green supply chain management using total interpretive structural modeling. IFAC-PapersOnLine, 48(3), 1688-1694.

22. Fiksel, J. (1996). Design for environment: Creating eco-efficient products and processes. New York: McGraw-Hill.

23. Gatenby, D.A \& Foo, G (1990) Design for X (DFX): Key to competitive, profitable products. AT\&T Technical Journal. 69: 2-15

24. Gopalakrishnan, K., Yusuf, Y. Y., Musa, A., Abubakar, T., \& Ambursa, H. M. (2012). Sustainable supply chain management: A case study of British Aerospace (BAe) Systems. International Journal of Production Economics, 140(1), 193-203.

25. Gungor, A., \& Gupta, S. M. (1999). Issues in environmentally conscious manufacturing and product recovery: a survey. Computers \& Industrial Engineering, 36(4), 811-853.

26. Guide, V. D. R., Jayaraman, V., \& Linton, J. D. (2003). Building contingency planning for close-loop supply chains with product recovery. Journal of Operations Management, 21, 259-279.

27. Guide, V. D. R., \& Srivastava, R. (1998). Inventory buffers in recoverable manufacturing. Journal of Operations Management, 16, 551-568.

28. Jayant, A., \& Azhar, M. (2014). Analysis of the barriers for implementing green supply chain management (GSCM) practices: an interpretive structural modeling (ISM) Approach. Procedia Engineering, 97, 2157-2166.

29. Hakansson, H., 1987, Industrial Technological Development: A Network Approach (London: Croom Helm).

30. Hamel G., and Prahalad C.K., (1989) "Strategic Intent” Harvard Business Review,May -June, 1989, Vol. 67. No. 3. pp63-78

31. Hanna, M.D. \& Newman, W.R. (1995). 'Operations and environment: an expanded focus for TQM', International Journal of Quality \& Reliability Management, vol. 12, no. 5, pp. 38-53.

32. Harland, C. M. (1996). Supply chain management: Relationships, chains and networks. British Journal of Management, 7, S63-S80.

33. Johnson, P. F. (1998). Managing value in reverse logistics system. Logistics and Transportation Review, 34, $217-227$.

34. Kelle, P. and Silver, E.A. (1989) "Forecasting the returns of reusable containers," Journal of Operations Management, vol. 8, no. 1, pp. 17-35, 1989. 
35. Kaushik, A., Kumar, S., Luthra, S., \& Haleem, A. (2014). Technology transfer: enablers and barriers a review. International Journal of Technology, Policy and Management, 14(2), 133-159.

36. Kausar, K., Garg, D., \& Luthra, S. (2017). Key enablers to implement sustainable supply chain management practices: An Indian insight. Uncertain Supply Chain Management, 5(2), 89-104.

37. Kopicki, R. J., Legg, L., Berg, L. M. J., Dassapa, V., \& Maggioni, C. (Eds) (1993). Reuse and recycling: Reverse logistics opportunities. Oak Brook, IL: Council of Logistics Management.

38. Kumar, S., Luthra, S., \& Haleem, A. (2013). Customer involvement in greening the supply chain: an interpretive structural modeling methodology. Journal of Industrial Engineering International, 9(1), 1-13.

39. Kumar, S., Luthra, S., \& Haleem, A. (2014). Critical success factors of customer involvement in greening the supply chain: an empirical study. International Journal of Logistics Systems and Management, 19(3), 283-310.

40. Lai, K.H. \& Wong, C.W.Y (2012) Green logistics management and performance: Some empirical evidence from Chinese manufacturing exporters Vol- 40, Issue 3, pp.267-282.

41. Lai, K, Wu, S.J. \& Wong, C.W.Y. (2013) Did reverse logistics practices hit the triple bottom line of Chinese manufacturers? International Journal of Production. Economics, 146 (1) (2013), pp. 106-117

42. Lorenzoni, G. and Ornati, O., 1988, Constellations of firms and new ventures. Journal of Business Venturing, 3, 4157.

43. Lamming, R. (1989). The causes and effects of structural change in the European automotive components industry. Working Paper of the International Motor Vehicle Program. MIT, Cambridge, MA, USA.

44. Luthra, S., Kumar, V. \& Haleem, A., Barriers to implement green supply chain management in automobile industry using interpretive structural modelling technique - An india perspective, journal of industrial engineering and management, vol 4, no.2, pp. $231-257,2011$.

45. Luthra, S., Kumar, S., Garg, D., \& Haleem, A. (2015). Barriers to renewable/sustainable energy technologies adoption: Indian perspective. Renewable and Sustainable Energy Reviews, 41, 762-776.

46. Mitra, S. and P. P. Datta (2014), "Adoption of Green Supply Chain Management Practices and their Impact on Performance: An Exploratory Study of Indian Manufacturing Firms", International Journal of Production Research, Vol. 52, No. 7, pp. 2085-2107

47. Min, H., Ko, H. J., \& Ko, C. S. (2006). A genetic algorithm approach to developing the multi-echelon reverse logistics network for product returns. Omega, 34, 56-69.

48. Navin Chandra, D. (1991). Design for environment ability. Design Theory and Methodology, 31, 99-124.

49. Nagorney, A., \& Toyasaki, F. (2005). Reverse supply chain management and electronic waste recycling: A multitiered network equilibrium framework for e-cycling. Transportation Research Part E: Logistics and Transportation Review, 41, 1-28.

50. Ninshiguchi, T., 1994, Strategic Industrial Sourcing: The Japanese Advantage (Oxford: Oxford University Press).

51. Oliver, R. K., \& Webber, M. D. (1982). Supply chain management: Logistics catches up with strategy. In M. Christopher (Ed.), Logistics: The strategic issues. London: Chapman and Hall.

52. Power, D. (2005). Supply chain management integration andimplementation: A literature review. Supply Chain Management: An International Journal, 10(4), 252-263.

53. Pohlen, T. L., \& Farris, M. T. (1992). Reverse logistics in plastic recycling. International Journal of Physical Distribution \& Logistics Management, 22, 35-47.

54. Ravi, V., Ravi, S., \& Tiwari, M. K. (2005). Analyzing alternatives in reverse logistics for end-of-life computers: ANP and balanced scorecard approach. Computers \& Industrial Engineering, 48, 327-356.

55. Rao, P. and Holt, D. (2005). Do green supply chains lead to competitiveness and economic performance? International Journal of Operations and ProductionManagement, 25(9), 898-916.

56. Roy, R., \& Whelan, R. C. (1992). Successful recycling through value-chain collaboration. Long Range Planning, 25, 62-71.

57. Sarkis, J., \& Cordeiro, J. (2001). An empirical evaluation of environmental efficiencies and firm performance: Pollution prevention versus end-of-pipe practice. European Journal of Operational Research, 135, 102-113.

58. Scott, C., Lundgren, H., Thompson, P. (2011), Guide to Supply Chain Management, SpringerVerlag Berlin Heidelberg, p-209.

59. Shih, L. (2001). Reverse logistics system planning for recycling electrical appliances and computers in Taiwan. Resources, Conservation, and Recycling, 32, 55-72.

60. Slack, N., 1991, The Manufacturing Advantage (London: Mercury Business Books).

61. Stevens, G. C. (1989). Integrating the supply chain. International Journal of Physical Distribution and Materials Management, 19(8), 3-8.

62. Stock, J. (1998). Development and implementation of reverse logistics programs. Oak Brook: Council of Logistics Management.

63. Srivastava, S. K., \& Srivastava, R. K. (2006). Managing product returns for reverse logistics. International Journal of Physical Distribution and Logistics Management, 36, 524-546. 
64. Srivastava, S. (2007). Green supply-chain management: A state-of-the-art literature review. International Journal of Management Reviews, 9(1), 53-80.

65. Stock, J. (1998). Development and implementation of reverse logistics programs. Oak Brook: Council of Logistics Management.

66. Taleb, K. N., \& Gupta, S. M. (1997). Disassembly of multiple product structures. Computers \& Industrial Engineering, 32, 949-961.

67. Tang, C.S. \& Zhou, S.(2012) Research advances in environmentally and socially sustainable operations European Journal of Operational Research., Vol. 223 (3), 585-594

68. Tibben-Lembke, R. S. (2002). Life after death: Reverse logistics and the product life cycle. International Journal of Physical Distribution \& Logistics Management, 32, 223-244.

69. Umeda, Y., Tsukaguchi, H., \& Li, Y. (2003). Reverse logistics system for recycling: Efficient collection of electrical appliances. Proceedings of the Eastern Asia Society for Transportation Studies, 4, 1319-1334.

70. Van Der Laan, E. A., Salomon, M., \& Dekker, R. (1996). Product remanufacturing and disposal: A numerical comparison of alternative control strategies. International Journal of Production Economics, 45, 489-498.

71. Van Der Laan, E. A., \& Salomon, M. (1997). Production planning and inventory control with remanufacturing and disposal. European Journal of Operations Research, 102, 264-278.

72. Walker, H. and N. Jones (2012), "Sustainable Supply Chain Management Across the UK Private Sector", Supply Chain Management: An International Journal, Vol. 17, No. 1, pp. 15-28.

73. Walton, S., Handfield, R., \& Melynk, S. (1998). The green supply chain: Integrating suppliers into environmental management processes. International Journal of Purchasing and Materials Management, 34(2), 2-11

74. White, C.D., Masanet, E., Rosen, C.M. \& Beckman, S.L. (2003) Product recovery with some byte: an overview of management challenges and environmental consequences in reverse manufacturing for the computer industry, Journal of Cleaner Production, Vol. 11, pp.445-458

75. Womack, J. P., Jones, D. T. and Roos, D., 1991, The Machine That Changed the World (New York: HarperCollins).

76. Wood, A. (1997). Extending the supply chain: Strengthening links with IT. Chemical Week, 159(25), 26.

77. Wu, H. J., \& Dunn, S. C. (1995). Environmentally responsible logistics system. International Journal of Physical Distribution \& Logistics Management, 25, 20-39.12.

78. Wu, J., Dunn, S., \& Forman, H. (2012). A Study on Green Supply Chain Management Practices among Large Global Corporations. Journal of Supply Chain and Operations Management, 10(1), 182.

79. Zhang, H. C., Kuo, T. C., Lu, H., \& Huang, S. H. (1997). Environmentally conscious design and manufacturing: A state of the art survey. Journal of Manufacturing Systems, 16, 352-371.

80. Zhou, Z., Cheng, S., \& Hua, B. (2000). Supply chain optimization of continuous process industries with sustainability considerations. Computers \& Chemical Engineering, 24(2), 1151-1158.

81. Zhu, Q., \& Sarkis, J. (2004). Relationships between operational practices andperformance among early adopters of green supply chain management practices in Chinese manufacturing enterprises. Journal of Operations Management, 22, 265-289.

82. Zhu, Q., Sarkis, J., \& Lai, K. H. (2007a). Initiatives and outcomes of green supply chain management implementation by Chinese manufacturers. Journal of Environmental Management, 85(1), 179-189.

83. Zhu, Q., Sarkis, J., \& Lai, K. H. (2007b). Green supply chain management: pressures, practices and performance within the Chinese automobile industry. Journal of Cleaner Production, 15(11), 1041-1052.

84. Zhu, Q., Sarkis, J., \& Lai, K. H. (2008a). Green supply chain management implications for "closing the loop". Transportation Research Part E: Logistics and Transportation Review, 44(1), 1-18.

85. Zhu, Q., Sarkis, J., \& Lai, K. H. (2008b). Confirmation of a measurement model for green supply chain management practices implementation. International Journal of Production Economics, 111(2),

86. Zhu, Q., J. Sarkis and K. H. Lai (2012), "Examining the Effects of Green Supply Chain Management Practices and their Mediations on Performance Improvements", International Journal of Production Research, Vol. 50, No. 5, pp. 1377-1394. 